Journal of British Studies 59 (April 2020): 315-342. doi:10.1017/jbr.2019.291

(C) The North American Conference on British Studies, 2020. This is an Open Access article, distributed under the terms of the Creative Commons Attribution licence (http://creativecommons.org/licenses/by/4.0/), which permits unrestricted re-use, distribution, and reproduction in any medium, provided the original work is properly cited.

\title{
"The People Who Write to Us Are the People Who Don't Like Us": Class, Gender, and Citizenship in the Survey of Sickness, 1943-1952
}

\section{Daisy Payling}

\begin{abstract}
The Second World War and the rise of social medicine in 1940s Britain reframed population health as a social problem in need of state investigation. The resulting government inquiry, the Survey of Sickness, sampled the whole adult population of England and Wales, engaging a broad and diverse cross-section in public health research for the first time. Complaints made against the Survey of Sickness reveal a complex set of relationships between different sections of the public and the British state. This article situates complaints about privacy, liberty, and wasted resources, as well as challenges to the authority of survey fieldworkers, in the context of wider resistance to postwar controls. By viewing these protests and criticisms in light of the material circumstances of the people who made them, this article argues that, for those with social, economic, and political capital, the role of the public in public health was up for negotiation in postwar Britain. The everyday politics of the survey's doorstep encounters were heavily influenced by gendered notions of home and citizenship. This exploration of how different sections of the public were constructed by public health and how they responded to that construction describes the hierarchies of expertise under formation while illuminating how class and gender informed contemporary understandings of citizenship in the emerging postwar British state.
\end{abstract}

The essence of the sample survey differs in no essential from the familiar technique of the blood-count. In each, a tiny fraction only of the whole is examined, and from this deductions about the whole are made. In each, a measurement is made, while the vast multitude to whom it applies, whether human or cellular, swirls by unaware that it has been measured. —“Sample Surveys," Lancet 256, no. 6618 (1950): 22-23 (1950): 22-23, at 22

n July 1950, the Lancet declared that the sample survey as "a tool of medicosocial research" had "come to stay." It cited the Survey of Sickness, an inquiry carried out by the Government Social Survey department (or GSS) on behalf of the British Ministry of Health, and praised its ability to identify "where and whether

Daisy Payling is a senior postdoctoral research assistant at the University of Essex. She thanks the anonymous reviewers of Journal of British Studies for extremely helpful comments. She is also grateful to Alex Mold, Amy Edwards, Jessica Hammett, and Sara Sherwood for comments on earlier drafts and encouragement. This research was funded by the Wellcome Trust (WT 100586/Z/12/Z). Please direct any correspondence to daisy.payling@googlemail.com

1 "Sample Surveys," Lancet 256, no. 6618 (1950): 22-23, at 22. 
human needs" were being met. The Lancet's comparison of the sample survey with a "blood-count," implying that survey subjects were silent, passive bodies, ignored the role that the public played in providing information. While some members of the public might have "swirl[ed] by unaware" that the Ministry of Health was investigating people's experiences of sickness and health, many were aware. ${ }^{2}$ The national press, from the Daily Express to the Daily Mail and the Times, reported on the survey. They discussed the reliability of public responses and debated issues of privacy, reanimating allegations of spying and surveillance that had been leveled at the minister of information, Duff Cooper, and his government "snoopers" in 1940. More significantly, the "tiny fraction" of the population who were sampled and surveyed-around 300,000 from 1943 to 1952-were not merely "examined" but were actively engaged with public health. As an inquiry into whole population health, the survey targeted people from all walks of life. The sample included middle-class men, who were not often the subjects of public health measures in this period, and middle-class women, many of whom were all too used to government intrusion into their homes and lives under the auspices of civic duty and postwar reconstruction. ${ }^{3}$ In this article, I describe the attitudes and experiences of some of the people interviewed for the Survey of Sickness. In doing so, I demonstrate how women and men negotiated their role in public health while coming to understand what it meant and how it felt to be participants in government research in the immediate postwar period.

Setting the Survey of Sickness in the context of British public health and social inquiry in the 1940s and early 1950s, I show how the Second World War and the rise of social medicine encouraged the conception of whole population health as a social problem worthy of social investigation. I demonstrate how this concept produced an inclusive definition of the "public" in public health that was representative of the whole population, not just the sick and marginalized.

Yet as wartime controls continued into the postwar period, some members of the public grew increasingly frustrated with the state's role in their day-to-day lives. For some approached by the GSS, the Survey of Sickness bore the brunt of their frustrations. I used archival evidence of the "material practical encounters" of social surveys-instructions to and reports by fieldworkers, letters between staff at the GSS, the Ministry of Health, and the Central Office of Information Public Relations Office, and, most significantly, letters of complaint - to explore how different sections of the public reacted to being surveyed. ${ }^{4}$ While most people responded cooperatively, answering questions when asked, a few refused outright to be involved, and others wrote to complain about the process after the fact or resisted the survey through less conspicuous means: misleading interviewers or withholding information. Their complaints have left a clear paper trail for historians to follow, the most vivid of the "fragmentary traces" left behind by the ordinary people engaged by the GSS. ${ }^{5}$

\footnotetext{
2 "Sample Surveys."

${ }^{3}$ Virginia Berridge, Marketing Health: Smoking and the Discourse of Public Health in Britain, 1945-2000 (Oxford, 2007), 188; Caitriona Beaumont, Housewives and Citizens: Domesticity and the Women's Movement in England, 1928-64 (Manchester, 2013).

${ }^{4}$ Mike Savage, Identities and Social Change in Britain since 1940: The Politics of Method (Oxford, 2010), 12.

${ }^{5}$ Jon Lawrence, "Social-Science Encounters and the Negotiation of Difference in Early 1960s England," History Workshop Journal 77, no. 1 (2014): 215-39, at 216.
} 
These acts of resistance cannot be viewed unproblematically as representative of public feeling, as Louis Moss, director of the GSS, acknowledged: "The people who write to us are the people who don't like us." by these complaints were shared more widely, and an examination of these traces can reveal the complexities inherent in relationships between members of the public and the British state in the aftermath of World War II.

The complaints, often tinged with Conservative Party rhetoric, can be broadly categorized into four interrelated themes. The first three related to the survey as a violation of privacy, an infringement of liberty, and a waste of government money and individuals' time. The fourth theme concerned the conduct of fieldworkers, most of whom were women. By situating complaints alongside extracts from popular newspapers and official reports of non-compliance and by paying close attention to demographic markers of class and gender, I explore how a diverse public made up of working-class and middle-class men and women, responded to being surveyed. In doing so, I show that certain sections of the public were more able than others to respond to the survey and to affect change in its process. Demographic information provided in fieldworkers' reports, though patchy and uneven, suggests that complaints largely came from middle-class households. By acknowledging that the complaints came from exceptionally "vocal . . . individuals"- those with the means and confidence to complain-we can also use such complaints to shed light on the reported actions of those with less power and agency (such as working-class women), whose assumed ignorance and apathy can be reframed as a subtler form of resistance. ${ }^{7}$

While the reasons for complaint were broadly shared across class and gender lines, women and men tended to frame their complaints in different ways, and members of the public used varied methods of resistance and refusal. Through these different modes of resistance, individuals were able to rearticulate their relationships with the expanding state, expressing citizenship on their own terms. Complaints revealed how the everyday politics of these doorstep encounters were heavily influenced by gendered notions of home and citizenship. Exploring how different sections of the public were constructed by public health and how they responded to that construction can reveal the hierarchies of expertise under formation while illuminating how class and gender informed contemporary understandings of citizenship in the emerging postwar British state.

In making the whole population worthy of social investigation and seeking information that only the public could provide, the survey made itself vulnerable to public criticism. To a certain extent, the complaints received were an inevitable accompaniment to developments in social surveying and the privileging of the public's contribution to social knowledge. The survey gave public voices weight by design, and in turn had to adapt to their criticisms. But the complaints also revealed the limitations of relying on the public's contributions. Without public cooperation, a survey could falter. Even with cooperation, the complaints of some were enough to bring the

\footnotetext{
${ }^{6}$ The National Archives (hereafter TNA), RG 40/16, Health Index Survey: General Correspondence, Louis Moss to Stephen Heald, June 1950.

7 TNA, RG 40/133, Complaints Received from Members of the Public Interviewed by S. S. Investigators, Thomas Fife Clark to Louis Moss, 15 January 1947.
} 
Survey of Sickness to an end in 1952, weakening the faith in expertise on which the welfare state was formed. ${ }^{8}$

\section{FROM SOCIAL SURVEYS TO SOCIAL MEDICINE: THE DEVELOPMENT OF EVERYDAY HEALTH AS A SOCIAL PROBLEM IN 1940S BRITAIN}

The technological innovations of social surveys, medical statistics, and epidemiology were integral to the development of twentieth-century public health and its scientific credibility. ${ }^{9}$ Public health's expansion and interpretation of statistics played a vital role in determining how population health was viewed by policy makers and what actions should be taken to improve it. ${ }^{10}$ But the innovations also encouraged a new, more comprehensive conception of the public as objects of and participants in research and the governance of health. ${ }^{11}$ Much of the literature on the development of social surveys in the nineteenth and early twentieth centuries has been influenced by Foucauldian notions of surveillance and power, positioning the survey as "an instrument of order and control." 12 Surveys were developed as a method of mapping "the unknown slums" in cities expanding under industrial capitalism. Middle-class philanthropists and social reformers utilized the survey "to know, to contain, to control, and to speak about the poor," often using terms of moral judgment. ${ }^{13}$ In the twentieth century, social scientists picked up the mantle, conducting social surveys that focused on a public of unemployed or working people "whose lives were impoverished and marginalised" over those who were "prosperous and secure." 14 With a few notable exceptions which studied "ordinary" people's experiences, British social research continued to focus on so-called "social problems" well into the post-war period. ${ }^{15}$ The interest in those deemed to be impoverished and marginalized was widely shared by researchers, social workers, the clergy, police, and doctors and within public health. Throughout the nineteenth and early twentieth centuries, public health largely focused on women and children, sending sanitary inspectors and health visitors into communities to monitor and educate. ${ }^{16}$ Accounts of these social surveys indicate that research was concerned with classifying

${ }^{8}$ David Kynaston, Austerity Britain, 1945-51 (London, 2007), 24.

9 Theodore Porter, Trust in Numbers: The Pursuit of Objectivity in Science and Public Life (Princeton, 1995), 202-5.

${ }^{10}$ Simon Szreter, "Rethinking McKeown: The Relationship between Public Health and Social Change," American Journal of Public Health 92, no. 5 (2002): 722-25.

11 Tom Crook, Governing Systems: Modernity and the Making of Public Health in England, 1830-1910 (Oakland, 2016), 295.

12 David Armstrong, Political Anatomy of the Body: Medical Knowledge in Britain in the Twentieth Century (Cambridge, 1983), 51.

${ }^{13}$ Seth Koven, "The Dangers of Castle Building-Surveying the Social Survey," in The Social Survey in Historical Perspective, ed. Martin Bulmer, Kevin Bales, and Kathryn Kish Sklar (Cambridge, 1991), 36876 , at 370.

${ }^{14}$ Jon Lawrence, “Class, 'Affluence,' and the Study of Everyday Life in Britain c.1930-64,” Cultural and Social History 10, no. 2 (2013): 273-99, at 274-75.

${ }^{15}$ Lawrence, "Class, Affluence," 282; Joe Moran, "Mass-Observation, Market Research, and the Birth of the Focus Group, 1937-1997," Journal of British Studies 47, no. 4 (2008): 827-51.

${ }^{16}$ Berridge, Marketing Health, 188; Celia Davies, “The Health Visitor as Mother's Friend: A Woman's Place in Public Health, 1900-14," Social History of Medicine 1, no. 1 (1988): 39-59. 
populations, aiming to pathologize the "morally deviant," separating them from the respectable and legitimate. ${ }^{17}$ Power lay with the surveyors and with the reformers, experts, and policy makers who commissioned the surveys. ${ }^{18}$ This relationship was "was emphatically not dialogic." The survey's "language of graphs, tables and statistics defined an elite readership and excluded those whom it surveyed."19 Those surveyed were constructed as a "social problem," objects necessitating study by experts.

The development in the 1920s and 1930s of public-opinion research and surveys that sampled whole populations complicates this narrative. Surveys began to focus on publics beyond the marginalized poor, and at the same time, wider reportage and higher literacy rates enabled more people to engage with the data that such surveys produced. Sarah Igo has shown how American society was influenced by surveys. Modern survey methods "helped to forge a mass public," creating a measurable average, a "typical American," out of a heterogeneous population. Through detailing how ordinary Americans experienced "anger, skepticism, and relief" as they wrestled with survey findings, Igo shows that, by the mid-twentieth century, ordinary people understood and engaged with the "language of graphs," relating statistical findings to themselves, and themselves to statistical definitions of "normal." 20 By giving ordinary people a voice in society, public-opinion surveys could be "democratising." 21 The advent of representative sampling also introduced an element of obligation; participating in a survey could take on the form of civic duty. 22

In Britain, social surveying remained rooted in a prominent culture of philanthropy throughout the 1930s, and governments were initially wary of being seen to follow public opinion, even that of a fully enfranchised public. ${ }^{23}$ This position began to change as the rise of mass markets, the expansion of mass communication, and the experience of "total war" encouraged politicians to seek out public opinion in order to govern more effectively and efficiently. ${ }^{24}$ From the Second World War onward, due to the importance placed on civilian contributions to the war effort, understanding everyday life and ordinary people became vital. ${ }^{25}$ From 1939 onward, British government departments made more frequent use of direct-response social surveys. This trend was initially met with criticism from parliamentarians and the press, who objected to government-sponsored opinion polling on the grounds that it represented a "dangerous accretion of power to the executive." 26 The furor

\footnotetext{
${ }^{17}$ Savage, Identities and Social Change, 7.

${ }^{18}$ Catherine Marsh, "Informants, Respondents and Citizens," in Essays on the History of British Sociological Research, ed. Martin Bulmer (Cambridge, 1985), 206-27, at 206.

${ }^{19}$ Koven, "Dangers of Castle Building," 370.

${ }^{20}$ Sarah E. Igo, The Averaged American: Surveys, Citizens, and the Making of a Mass Public (Cambridge, MA, 2007), 282-85.

${ }^{21}$ Thomas Osborne and Nikolas Rose, "Do the Social Sciences Create Phenomena? The Example of Public Opinion Research,” British Journal of Sociology 50, no. 3 (1999): 367-96, at 379.

22 Alain Desrosières, The Politics of Large Numbers: A History of Statistical Reasoning, trans. Camille Naish (Cambridge, 1998), 224.

${ }^{23}$ Charlotte Greenhalgh, "The Travelling Social Survey: Social Research and Its Subjects in Britain, Australia and New Zealand, 1930s-1970s," History Australia 13, no. 1 (2016): 124-38, at 125.

${ }^{24}$ Osborne and Rose, "Do the Social Sciences Create Phenomena?," 379.

${ }^{25}$ Lawrence, "Class, 'Affluence," 278.

${ }^{26}$ Laura DuMond Beers, "Whose Opinion? Changing Attitudes towards Opinion Polling in British Politics, 1937-1964," Twentieth Century British History 17, no. 2 (2006): 177-205, at 181 and 189.
} 
was such that the government turned its attention from opinion polling to fact finding. ${ }^{27}$

In 1941, the GSS emerged with the intention of investigating so-called "social problems." Its aim was "establishing facts and the attitudes of the public towards these facts." ${ }^{28}$ By planning to investigate social problems in this context, the GSS meant to map the everyday concerns of health, nutrition, and labor. In wartime, the everyday had become a social problem, and the focus of enquiry had shifted from the marginalized to the whole population. ${ }^{29}$

The Times saw this development as a democratic advancement, "a new and quantitative bridge" between government and the British public. ${ }^{30}$ On being asked for information about their lives and how they "felt about their housing, living standards and their futures . . . people were encouraged to believe that their views and experiences mattered." 31 Citizens came to see the information produced as a right, something the government had a "duty" to provide. ${ }^{32}$ Paired with the expectation in wartime that the government should "continually 'do something' in all spheres," this belief outweighed the "popular cherishing of privacy" and reinforced the obligation to participate. ${ }^{33}$ Catherine Marsh suggests this shift led to a "new respect" for those studied; they were both participants in and "subjects of research." 34 Members of the public were approached directly and encouraged to speak their mind rather than being observed and reported on by "expert" informers such as health visitors. ${ }^{35}$ But with a direct approach came the expectation that the public would respond appropriately within the parameters of the survey, providing answers to questions when asked. The GSS may have contributed to democracy by recording people's feelings and experiences, but this was democracy "mediated by experts rather than by direct election." 36 As David Vincent explains, when the arm of the state reached into the homes of its citizens, people weighed their rights to privacy against the benefits afforded to them by surveillance. ${ }^{37}$ In wartime, a degree of sacrifice was accepted, not just of privacy but of consumer choice as well, with rationing and market controls. As wartime controls continued into the postwar period, however, the scales began to tip. ${ }^{38}$ Sitting in opposition, the Conservative Party capitalized on this feeling, equating surveys and surveillance-in their anti-socialist rhetoric, "snoopers"-with

${ }^{27}$ Beers, "Whose Opinion?," 190.

${ }^{28}$ Kathleen Box and Geoffrey Thomas, "The Wartime Social Survey," Journal of the Royal Statistical Society 107, nos. 3-4 (1944): 151-89, at 151; Louis Moss, The Government Social Survey: A History (London, 1991), 4.

${ }^{29}$ Jon Agar, The Government Machine: A Revolutionary History of the Computer (Cambridge, 2003), 227-28.

30 "War-Time Social Survey," Times (London), 28 March 1942, 5.

${ }^{31}$ Selina Todd, "Class, Experience and Britain's Twentieth Century," Social History 39, no. 4 (2014): $489-508$.

32 Brendan Maartens, "From Propaganda to 'Information': Reforming Government Communications in Britain," Contemporary British History 30, no. 4 (2016): 542-62, at 543.

${ }^{33}$ Jose Harris, "War and Social History: Britain and the Home Front during the Second World War," Contemporary European History 1, no. 1 (1992): 17-35, at 25, 31-32.

${ }^{34}$ Marsh, "Informants, Respondents and Citizens," 215.

${ }^{35}$ Greenhalgh, "Travelling Social Survey," 133.

${ }^{36}$ Agar, Government Machine, 229.

${ }^{37}$ David Vincent, Privacy: A Short History (Cambridge, 2016), 101.

${ }^{38}$ Mark Roodhouse, Black Market Britain: 1939-1955 (Oxford, 2013), 238. 
rationing, queues, and shortages, contrasting them with their proposals of "liberty"the "freedom to earn all you can and buy what you like"-in attempts to whip up support among middle-class voters. ${ }^{39}$ The GSS continued to imagine the whole population as a social problem necessitating investigation. Although most members of the public tolerated this view, it did not go uncontested.

The GSS emerged just as interest in the discipline of social medicine reached a high point in Britain. ${ }^{40}$ Social medicine was considered by some to be the "radical" arm of public health. Its practitioners viewed population health as a social problem and thought medicine had a political role to play in addressing inequality. ${ }^{41}$ In the 1940s, social medicine emphasized the dynamic relationship between health and social factors and aimed to explore how social and economic change affected health. Practitioners refused to view health and sickness as absolute states and instead used statistical methods to examine "norms and ranges of variation," bringing the whole public under the purview of public health. ${ }^{42}$ As a discipline, social medicine focused on building statistical links between "life hazards, poor environments and poor health" and conceived of medicine as a social science that examined the social relations of health and aimed to rectify inequalities. ${ }^{43}$ This "new epidemiology" turned "the private inner states of individuals into public objects of government," reinforcing the connection between social medicine and political action. ${ }^{44}$ Debates around social medicine intersected with those around the planning of a national health service, drawing the suspicion of clinicians and doctors in questioning their focus on individual patients and in looking beyond their professional expertise to the field of medical statistics. ${ }^{45}$ As a political project, social medicine also identified whole population health as a social problem and looked to social science to inform health policy.

These ideas influenced the development of the GSS's 1943 Survey of Sickness, which aimed to measure the incidence of illness and injury in the whole population. During the war, the government had come to share social medicine's perception of whole population health as a "social problem," and the ministries of information and health reached out to researchers trained in medical statistics who were willing to apply their science in a government investigation. ${ }^{46}$ Although 1942 broke previous records for low maternal and infant mortality and recorded a low incidence of infectious diseases and a low death rate, there were increased anxieties around the

\footnotetext{
${ }^{39}$ Ina Zweiniger-Bargielowska, "Explaining the Gender Gap: The Conservative Party and the Women's Vote, 1945-1964," in The Conservatives and British Society: 1880-1990, ed. Martin Francis and Ina Zweiniger-Bargielowska (Cardiff, 1996), 193-224.

${ }^{40}$ Shaun Murphy and George Davey Smith, "The British Journal of Social Medicine: What Was in a Name?," Journal of Epidemiology and Community Health 51, no. 1 (1997): 2-8, at 2.

${ }^{41}$ Murphy and Davey Smith, "The British Journal of Social Medicine," 2

${ }^{42}$ Murphy and Davey Smith, 3.

${ }^{43}$ Ann Oakley and Jonathan Barker, eds., Private Complaints and Public Health: Richard Titmuss on the National Health Service (Bristol, 2004), 5-6.

${ }^{44}$ Rhodri Hayward, The Transformation of the Psyche in British Primary Care, 1880-1970, (London, 2014), 77-80.

${ }^{45}$ Oakley and Barker, Private Complaints, 5-6; see also Dorothy Porter, "From Social Structure to Social Behaviour in Britain after the Second World War," Contemporary British History 16, no. 3 (2002): 58-80.

${ }^{46}$ Dorothy Porter, "Social Medicine and the New Society: Medicine and Scientific Humanism in MidTwentieth Century Britain,” Journal of Historical Sociology 9, no. 2 (1996): 168-87, at 182; Edward Higgs, "Medical Statistics, Patronage and the State: The Development of the MRC Statistical Unit, 1911-1948," Medical History 44, no. 3 (2000): 323-40, at 340; Armstrong, Political Anatomy of the Body, 48.
} 
effect of wartime food rationing, working hours, and stress on people's health. ${ }^{47}$ These concerns were exacerbated by reports from the reduced number of general practitioners about increased workloads, and complaints from members of the public that they were feeling "below par."48 In July 1943, Dr. Stephen Taylor of the Ministry of Information wrote to Dr. Percy Stocks, chief medical statistician of the General Register Office, stating the need for an inquiry into the general health of the population. Taylor raised the issue of public concerns about poor wartime health. ${ }^{49}$ "Alarmist rumours" about the public's health were seen to adversely affect wartime morale and undermine confidence in the government. ${ }^{50}$ Stocks agreed: the need for reliable, more specific statistics about the general health of the population was "very evident." He explained to Taylor that Sir Wilson Jameson, chief medical officer at the Ministry of Health, and a keen proponent of social medicine himself, had requested that he liaise with the GSS to develop an inquiry. ${ }^{51}$ Together with GSS staff, Stocks piloted the Survey of Sickness in October 1943.

The survey aimed to be a "scientific" investigation of whole population health and used emerging statistical methods to "promote confidence" in its results and alleviate public concerns. ${ }^{52}$ It asked randomly sampled members of the public to report on their health over the preceding three months, encouraging them to include details about specific symptoms and illnesses and how much time they had taken off work. Those selected were intended to be a "representative sample" of the civilian population in England and Wales between the ages of sixteen and sixty-four. ${ }^{53}$ Each month, around three thousand people were selected, each time from a different set of regional districts representative of the variations of rural and urban living in England and Wales. ${ }^{54}$ Between 1943 and 1952, trained fieldworkers, mostly women, questioned around 300,000 people in their homes and at their workplaces. ${ }^{55}$ Survey participants were also asked questions about their personal and material circumstances and social status. From their answers, the survey provided data on sickness rates by age, sex, and income as well as on medical consultation and on days lost to incapacity. The results were published regularly in the Bulletin of the Ministry of Health and the Registrar General's Quarterly Return. ${ }^{56}$

The findings of the Survey of Sickness contributed to social medicine in important ways, shifting the focus of research to whole populations by questioning what it meant to be "sick" or "healthy." 57 The survey found that when questioned, "more than half will complain of some illness," a statistic the Daily Mail could not

\footnotetext{
${ }^{47}$ Stephen Taylor, "The Survey of Sickness, 1943-52: Was Our Survey Really Necessary?," Lancet 271, no. 7019 (1958): 521-523, at 521.

48 Taylor, "Survey of Sickness," 521.

49 TNA, RG 26/24, Survey of Sickness: Dr Stock's Correspondence with Social Survey, Stephen Taylor to Percy Stocks, 24 July 1943; Higgs, "Medical Statistics, Patronage and the State," 325.

${ }^{50}$ Moss, Government Social Survey, 157.

${ }^{51}$ Murphy and Davey Smith, "The British Journal of Social Medicine," 6.

52 Porter, Trust in Numbers, 200.

${ }^{53}$ Patrick Slater, Survey of Sickness: October 1943 to December 1945 (London, 1946), 1.

${ }^{54}$ Slater, Survey of Sickness, 1.

55 Taylor, "Survey of Sickness, 1943-52," 522.

${ }^{56}$ Moss, Government Social Survey, 157-58.

${ }_{57}$ TNA, RG 26/24, Survey of Sickness: Dr Stock's Correspondence with Social Survey, Percy Stocks to Louis Moss, 2 December 1946.
} 
dismiss as "unimportant."58 This finding helped to redefine what was "normal" and what was "healthy" and provoked further scrutiny of whole population health. ${ }^{59}$ The expanded focus of social medicine understandably brought new members of the public to the attention of public health. Although the GSS claimed that the public had "become familiar" with sampling methods and that their "application to social problems" was "generally accepted," certain sections of the public found themselves the subjects of social investigation for the first time. ${ }^{60}$ These people may have been familiar with survey methods intellectually but not with how it felt to be subjected to them. Rather than the usual survey subjects of women and the marginalized poor, middle-class households (men included) were now placed under the lens of the survey, and these newer publics did not always behave as the surveyed should. Endowed with more social, economic, and political capital, and shored up by antisocialist political rhetoric, these people could more easily speak back to public health. Rattled by what they perceived as increasing government intrusion into their lives when they felt they had "sacrificed most" already under wartime rationing, some did speak back. ${ }^{61}$ Positioning themselves in their complaints about the Survey of Sickness as the "subject[s] of rights" as well as of research, members of middleclass households called into question top-down narratives of expertise and the authority of state representatives, rearticulating their relationships as private individuals within a changing state intent on making "public objects" of them. ${ }^{62}$

\section{READING RESISTANCE: LOCATING THE PUBLIC IN COMPLAINTS}

Percy Stocks viewed the public as active participants in research rather than passive objects. He trusted all of those sampled for the Survey of Sickness to know and be able to describe their own health. Stocks anticipated that the survey might face criticism for this view; "non-medical people" with "an exaggerated idea of the precision of what doctors write . . . compared with what they tell their patients" might find fault in his methods. ${ }^{63} \mathrm{He}$ did not, however, anticipate receiving complaints from those surveyed. Rates of compliance were generally high throughout the duration of the survey. GSS director Louis Moss maintained throughout the 1940s that very few peopleless than 2 percent-refused to take part in his department's surveys. ${ }^{64}$ GSS researchers working on the Survey of Sickness from 1943 to 1952 evidently expected high response rates. Fieldworkers insisted that "everybody welcomes a sympathetic listener," and Stocks himself wrote that people were often "rather over anxious" to provide information. ${ }^{65}$ One fieldworker, Edna Grossman, found three failed

58 "Well, How Do YOU Feel?," Daily Mail (London), 5 February 1958.

${ }^{59}$ Armstrong, Political Anatomy of the Body, 79.

${ }^{60}$ Slater, Survey of Sickness, 1.

${ }^{61}$ Roodhouse, Black Market Britain, 260.

${ }^{62}$ Crook, Governing Systems, 295; Hayward, Transformation of the Psyche in British Primary Care, 77-80.

${ }^{63}$ TNA, RG 26/24, Survey of Sickness: Dr. Stock's Correspondence with Social Survey, Percy Stocks to Pixie Wilson, 14 July 1944.

${ }^{64}$ TNA, RG 40/134, Complaints Received from Members of the Public Interviewed by S. S. Investigators, Louis Moss to Gordon Touche, 21 December 1949.

${ }^{65}$ TNA, RG 26/24, Survey of Sickness: Dr Stock's Correspondence with Social Survey, Percy Stocks to Fife Clarke, 13 April 1944; Slater, Survey of Sickness, 10. 
interviews ("one person too deaf to interview... one refusal, and another who had left her husband [I got all the "low-down" from a neighbour!"]) enough to describe Wandsworth as "not . . . a happy hunting ground." 66 But while a clear majority of people sampled for the Survey of Sickness agreed to take part, the Central Office of Information received complaints from some of those surveyed after the event. In January 1947, Thomas Fife Clark from the Public Relations department of the Central Office of Information wrote to inform Moss that they were getting "an average of one complaint a day. . . it would be a very bad thing for the Survey of Sickness . . . if these complaints continued to increase." 67 Complaints were still comparatively rare, but the rate of one a day, Fife Clark acknowledged, had him feeling "most anxious." He wanted the survey to keep "the good will of the public" and urged Moss to investigate "vocal and justified protests from individuals." 68

Complaints such as these offer useful insights into public perceptions and attitudes otherwise difficult to grasp. The philosopher Julian Baggini argues that "there is value in reflecting on what our complaints say about ourselves." ${ }^{\prime \prime 9}$ Reflections are possible because, as John Clarke observes, complaints require "going public."70 Whereas a grievance can remain private, the process of submitting a complaint to the relevant authority and investigation procedure makes it inherently public and leaves a record. Complaints represent a "hinterland" of "anxieties, doubts and frustrations," the public articulation of private grumblings shared by many people. ${ }^{71}$ Complaints tell us not only what some objected to but also what other members of the public acquiesced to. Furthermore, there is value in noting which people are able to make complaints and how they construct their grievances. In "going public" with a complaint, those writing to the GSS differentiated themselves from the general surveyed public and were marked out as "vocal" individuals. These people spoke back to the survey not only when prompted to but, by pushing beyond the parameters set by the survey, they also engaged with it on their own terms. In doing so, they rejected the collective enterprise of the survey for an individual relationship with the state conducted through correspondence. While many of those surveyed held a "desire to join the majority," to have their opinions and circumstances represented, others pushed back against being "statisticized."72 Letters of

${ }^{66}$ TNA, RG 40/198, Health Index Correspondence, Edna M. Grossmann to Mrs Edwards, 12 November 1946.

${ }^{67}$ TNA, RG 40/133, Complaints Received from Members of the Public Interviewed by S. S. Investigators, Fife Clark to Moss, 15 January 1947.

${ }^{68}$ TNA, RG 40/133, Complaints Received from Members of the Public Interviewed by S. S. Investigators, Fife Clark to Moss, 15 January 1947. Unfortunately there is no record of how many complaints were received. A Freedom of Information request has allowed access to sixty-nine complaints, but 215 pages in folders RG 40/133 and RG 40/134 remain closed. It is also unclear if these folders contain all the complaints made. Moss wrote frustrated letters to Fife Clark indicating that he was not receiving all the complaints, which suggests that there were more than we have record of.

${ }^{69}$ Julian Baggini, Complaint: From Minor Moans to Principled Protests (London, 2010), 3, 128.

${ }^{70}$ John Clarke, "Going Public: The Act of Complaining," in Complaints, Controversies and Grievances in Medicine: Historical and Social Science Perspectives, ed. Jonathan Reinarz and Rebecca Wynter (London, 2014), 259-69, at 261.

${ }^{71}$ Clarke, "Going Public," 261.

${ }^{72}$ Igo, Averaged American, 4; Sarah E. Igo, "Hearing the Masses: The Modern Science of Opinion in the United States," in Engineering Society: The Role of the Human and Social Sciences in Modern Societies, 1880-1980, ed. Kerstin Brückweh et al. (Basingstoke, 2012), 215-33, at 227. 
complaint gave the women and men who wrote them an opportunity to construct an individual subjectivity in response to the survey's attempts to aggregate them. Even correspondence of "the most impersonal" sort" could articulate "complex narratives about identity" or offer spaces for the "the ongoing devising of a plausible self."73 Writing in 1945, the novelist Elizabeth Bowen observed that wartime controls had sapped people's sense of self: "You used to know what you were like from the things you liked, and chose. Now there was not what you liked, and you did not choose." ${ }^{\prime 4}$ In response to the survey, some found that formal complaint, or the articulation of what they did not like, offered a restoration of self and a claim to individual freedom. Yet while complaints were important as individual expressions of dissatisfaction, the act of complaining resulted in the creation of a public record, now an archival source, and can be read as both an articulation of subjective experience and as an expression of a public feeling, albeit a formally constructed and unusually vocal one. ${ }^{75}$

Examination of these complaints reveal shared and overlapping points of tension in the relationships between members of the public and the state. Unfortunately, not all the complaints mentioned by Fife Clark were kept or passed on to Moss, and therefore it is impossible to quantify the exact number of complaints made against the GSS. However, sixty-nine complaints are available in the National Archives to read (with many more redacted), which, when read alongside letters and reports from interviewers, show how class and gender influenced how members of the public responded to public-health surveys and articulated their relationships with the state. Even the accessible complaints have been redacted under data protection legislation. Any demographic information mentioned here has been pieced together and inferred from contextual information provided in the complaints and in fieldworkers' reports, written as part of the investigation procedure. Out of sixty-nine complaints made available by the archive, forty were from men and seventeen from women, with the gender of the remaining twelve unspecified. Nineteen complainants show clear markers of being middle class, such as owning telephones or tennis courts, having domestic staff, or running their own businesses. Other complainants may have also been middle class, but it is impossible to know for certain.

Although it is difficult to know how widely held the grievances of such a small sample were, it is likely that these men and women were not alone in their struggle to reconcile their roles as individuals in the collective enterprise of government research and to make sense of the tensions between rights and obligations inherent in the foundational years of the welfare state. Issues recurred frequently in separate complaints and were framed in the language of broader public discourses around surveys articulated by the popular press. By tracing the use of these discourses by such "vocal" individuals-ones with the means and confidence to complain-we can infer the possibility that such grievances were shared by those less able to speak back to public health and the state. ${ }^{76}$

\footnotetext{
${ }^{73}$ Rebecca Earle, introduction to Epistolary Selves: Letters and Letter-Writers, 1600-1945, ed. Rebecca Earle (Aldershot, 1999), 1-14, at 2; Toby L. Ditz, "Formative Ventures: Eighteenth Century Commercial Letters and the Articulation of Experience," in Earle, Epistolary Selves, 59-78, at 62.

${ }^{74}$ Elizabeth Bowen, cited in Jenny Hartley, "'Letters Are Everything These Days': Mothers and Letters in the Second World War," in Earle, Epistolary Selves, 183-95, at 192.

75 Clarke, "Going Public," 262.

${ }^{76}$ Crook, Governing Systems, 296.
} 


\section{"I BELIEVE IT IS A SNOOPER, WHAT SHALL I DO?": PROBLEMS OF PRIVACY IN THE GOVERNMENT SOCIAL SURVEY}

The concerns raised in complaints about the GSS were revealing of both the survey and the publics it engaged. Although those complaining were a tiny percentage of the small surveyed sample of the population, they showed themselves to be part of a wider public discourse on surveys through their use of the word "snoopers" to refer to GSS staff. The term had gained a specific government context through the phrase "Cooper's Snoopers," coined to refer to the Ministry of Information's Wartime Social Survey department, criticized by contemporaries as "dictatorial and alien to the British political tradition." Developed under the minister of information, Duff Cooper, the department later became the GSS but failed to shake the "snooper" smear. ${ }^{77}$ Although, as Laura Beers suggests, the "Cooper's Snoopers" outcry was short-lived, "snooper" continued to be used throughout the 1940s and early 1950s as shorthand in popular newspapers such as the Daily Mail and Sunday Express. Because of its use in parliamentary debates, it even found its way into reporting by the Times. ${ }^{78}$ Popular newspapers have often been viewed as trivial or reactionary, prioritizing entertainment over politics, but with high readership rates, they reached a large number of people and played a role in framing how readers thought about issues. ${ }^{79}$ Across a week in July 1944, the Daily Express ran articles about the Survey of Sickness, framing complaints from members of the public as an outcry against "snoopers." Published letters were collated under the headline "Doctors and Patients Complain of Ministry Quiz. Door-to-Door 'Snoopers' Ask 'How Is Your Health?"80 "Snooper," with its negative and invasive connotations, was used to criticize the perceived increase in people employed to inspect functions within the home and the breach of privacy this represented. ${ }^{81}$

Such reservations highlight "the novelty" of social-scientific requests for information about "Ordinary" rather than marginal lives. ${ }^{82}$ They suggest that there were perceived limits to the information government should seek from its citizens. The Daily Express picked up on public concerns of privacy and state interference and succinctly distilled them into the word "snooper." Although parliamentary criticisms of government-sponsored surveys largely disappeared throughout the 1940s, the wider public held onto their concerns for longer. ${ }^{83}$ As part of public discourse, "snooper" was used by some of those writing to the GSS to complain about the survey; seven of sixtynine complaints mention the term. One GSS fieldworker reported being called "snooper" in person. A woman she interviewed in Marylebone, London, left the

77 Beers, "Whose Opinion?," 189-90, 198.

${ }^{78}$ Beers, 190; “The Duff Snoopers Hit Again,” Daily Mail (London), 2 August 1940, "The 'Snoopers' Were Out Again Yesterday," Daily Mail (London), 8 November 1941, "The Informer," Daily Mail (London), 17 November; "Sixty Thousand Pounds a Year!," Sunday Express (London), 11 June 1950; "Future of Ministry of Information," Times (London), 30 June 1944, 8, "Diplomatic Posts," Times (London), 5 February 1946, 2, “The Courteous Police,” Times (London), 10 December 1948, 5.

${ }^{79}$ Adrian Bingham, "Ignoring the First Draft of History? Searching for the Popular Press in Studies of Twentieth-Century Britain," Media History 18, no. 3-4 (2012): 311-26.

80 "Doctors and Patients Complain of Ministry Quiz," Daily Express (London), 27 July 1944, 3.

81 “The Informer" Daily Mail (London), 17 November 1949.

82 Greenhalgh, "Travelling Social Survey," 125.

${ }^{83}$ Beers, "Whose Opinion?," 190. 
room to use the telephone and was overheard asking, "I believe it is a snooper, what shall I do?' before showing her to the door, muttering 'snooper” under her breath." 84

"Snooper" acted as a catchall for several concerns held by the public, but certain methods employed by the GSS were felt specifically to be breaches of privacy. In the survey's early stages, redrafted instructions to interviewers noted the "difficulty most widely experienced. . . is that of asking the Income Group of the Chief Wage Earner." 85 Nine of sixty-nine complaints indicated this concern by mentioning salary or income. One man expressed shock at being asked questions of a "very personal nature . . my age . . . my employment . . my SALARY." "86 Another could not understand why such information was needed: "Please let me know what connection. . . there is between my daughter's health and my. . . Income?"87 Even those who understood the necessity of putting health in a social context, or trusted there was a reason, expressed annoyance with having to reveal their income on their doorstep. ${ }^{88}$ In response, the GSS issued each fieldworker with a card printed with income categories so the survey subject could "indicate . . his income" non-verbally. 89 The GSS assumed that wage earners were male, but this assumption could also suggest the "most widely experienced" difficulty was a problem often (but not exclusively) articulated by men, who were generally unused to being the subject of public health surveys.

Despite the measures taken, income questions remained a problem. One researcher noted in 1951, "[b]udget surveys, in fact, any survey dealing with income are likely to encounter some public criticism." $" 90$ Although concerns about income questions had been present since the 1930s, changing expectations of privacy in the postwar period combined with dissatisfaction with continuing wartime controls led to an increase in criticism of income questions. ${ }^{91}$ The response rate to the GSS's Household Expenditure Survey conducted over the course of 1953, amid a resurgence of the use of the word "snoopers" in the press, was a comparatively low 67 percent. A regional report specifically noted, "[t] he middle classes were inclined to be hostile, giving the impression that they resented enquiries into their private affairs. ${ }^{392}$ By the time of the 1957 GSS Family Expenditure Survey, response

${ }^{84}$ TNA, RG40/134, Complaints Received from Members of the Public Interviewed by S. S. Investigators, Fieldworker Report, 19 July 1950.

85 TNA, RG 26/26, Survey of Sickness: Instructions to Interviewers.

${ }^{86}$ TNA, RG 40/134, Complaints Received from Members of the Public Interviewed by S. S. Investigators, 3 May 1951; emphasis in original.

${ }^{87}$ TNA, RG 40/134, Complaints Received from Members of the Public Interviewed by

S. S. Investigators, 9 May 1951.

${ }^{88}$ TNA, RG 40/134, Complaints Received from Members of the Public Interviewed by S. S. Investigators, 9 May 1951.

89 TNA, RG 26/26, Survey of Sickness: Instructions to Interviewers.

${ }^{90}$ TNA, RG40/134, Complaints Received from Members of the Public Interviewed by

S. S. Investigators, William Kemsley to Louis Moss and Thomas Fife Clark, 29 November 1951.

${ }^{91}$ Hubert Llewellyn Smith, The New Survey of London Life and Labour, vol. 3, Survey of Social Conditions, part 1: The Eastern Area (London, 1932), 32-33; Vincent, Privacy, 80; Roodhouse, Black Market Britain, 253.

${ }^{92}$ Ministry of Labour and National Service, Report of an Enquiry into Household Expenditure in 19531954 (London, 1957), 11; Mark Dunton, "Public Cooperation with the Household Expenditure Enquiry, 1953-1954," National Archives Podcast Series, 20 January 2014, http://media.nationalarchives. gov.uk/index.php/public-cooperation-household-expenditure-enquiry. 
rates had fallen further to a "relatively low level" of just under 60 percent. ${ }^{93}$ The issue remained a sore spot for GSS director Louis Moss, who felt, through professionalism and "appropriate care," that his staff should have been able to reduce complaints and refusals to "insignificant proportions."94

Another common grievance articulated by men was the use of their wives, sisters, or mothers as proxies in their absence. Out of forty complaints from those clearly identified as men, nine were about this issue. For some, the concern was accuracy. One complainant, gender unknown, had no problem with the survey in principle but thought the proxy, a sister, might have provided "sketchy. . . incorrect" information. ${ }^{95}$ Others, all specified as male, considered the use of proxies a serious breach of privacy. One demanded in 1947, "[w] hat authority have you to question my wife . . . regarding my personal health?" 96 Another, whose job title was given by his wife as "Higher Executive Officer in the Civil Service," argued in 1950, "[ $\mathrm{t}]$ he method of securing information from a proxy, is . . to be deplored." He threatened to write to his MP and the press. ${ }^{97}$ A third was incensed that his mother had been used as a proxy. He located the fieldworker at her address and "remained at least a half an hour insulting [her]." 98 The fieldworker was so shaken that she took two months leave to consider tendering her resignation. ${ }^{99}$

These complaints are particularly significant as they came as a surprise to the GSS. The instructions to fieldworkers working on the Survey of Sickness made it clear that "in general a man is not a good proxy for a woman" but specifically mentioned that women - wives, daughters, and mothers - could be used as proxies for men. ${ }^{100}$ Many social researchers expected women to be knowledgeable about "stomachs, homes and emotions" and to be willing to report on them. ${ }^{101}$ As Claire Langhamer has shown, men and women experienced different meanings of home in the 1950s and developed different understandings of domestic privacy. 102 For Catriona Beaumont, the "salience of the household as a site of domestic labour by women" complicated understandings of home as a private "space of personal leisure." The notion that "the family is not private for women" puts the use of proxies in perspective. ${ }^{103}$ In the case of the nine complaints mentioned above, the survey trusted women's knowledge of their husbands'

${ }^{93}$ Moss, Government Social Survey, 197.

94 TNA, RG40/134, Complaints Received from Members of the Public Interviewed by S. S. Investigators, William Kemsley to Louis Moss and Thomas Fife Clark, 29 November 1951.

95 TNA, RG 40/133, Complaints Received from Members of the Public Interviewed by S. S. Investigators, 5 May 1948.

${ }^{96}$ TNA, RG 40/133, Complaints Received from Members of the Public Interviewed by S. S. Investigators, 6 May 1947.

97 TNA, RG 40/134, Complaints Received from Members of the Public Interviewed by

S. S. Investigators, 12 January 1950.

${ }^{98}$ TNA, RG 40/133, Complaints Received from Members of the Public Interviewed by S. S. Investigators, 17 June 1949.

99 TNA, RG 40/133, Complaints Received from Members of the Public Interviewed by S. S. Investigators, 17 June 1949.

100 TNA, RG 26/26, Survey of Sickness: Instructions to Interviewers, 6.

101 "Anatomy of the 'Don't Knows," December 1947, Mass Observation Archive, University of Sussex, SxMOAl/1/12/12/6, 15 .

${ }^{102}$ Claire Langhamer, "The Meanings of Home in Postwar Britain," Journal of Contemporary History 40, no. 2 (2005): 341-62, at 344.

103 Beaumont, Housewives and Citizens, 42. 
health more than the men in question did, and in doing so disrupted the privacy of home experienced by many men, which could be viewed differently by their wives.

This oversight was indicative of both the GSS's gendered assumptions of household knowledge and public health's inexperience in handling a male and middle-class public. By the end of the 1950s, the Ministry of Health still deemed it largely "inappropriate" to focus on men. ${ }^{104}$ This only changed through the emergence of smoking as a key public health issue and the identification of male smokers as a target within public health campaigns. In the 1940s, the GSS was prepared for men to be reluctant to talk to female fieldworkers about sensitive topics, but the resistance to routine survey methods took researchers by surprise. ${ }^{105}$ The complaints regarding questions about salaries and the use of wives and mothers as proxies suggest that some men were not only upset about being surveyed about their health but also had a problem with being surveyed in general and were mistrustful of survey methods. Through their complaints about privacy, a new male public brought previously unconsidered concerns to the attention of the GSS. At the same time, the use of a public rhetoric of "snoopers" indicate these concerns might have been held more widely, but these men, some of whom were middle class, had the social and cultural capital to articulate them and to influence the practice of the survey, negotiating their role within public health.

\section{"AN ENGLISHMAN'S HOME IS HIS CASTLE": LIBERTY AND THE LIMITS OF THE STATE}

The rhetoric of "snoopers" was often used in conjunction with the phrase "an Englishman's home is his castle" to articulate grievances around state intrusion and the perception of the survey as a threat to liberty as well as privacy. In April 1949, the Daily Express's satirical columnist Beachcomber encapsulated the feeling of escalating intrusion in a sketch entitled "Conversations in an Englishman's home." He imagined the following exchange:

Husband: "Who is that man in the bedroom, measuring my boots?"

Wife: "I think it's someone from one of the Ministries, dear. The one in the bathroom is testing water pressure for a Gallup poll.”

Husband: "And who let in the one who's going through my letters?"

Wife: "He broke in while I was out. He's from the secret police."

Husband: "Are there any other people in the house?"

Wife: "Only the man who came to see if we had any pigs concealed on the premises, and the fuel official they've billeted on us."106

Juxtaposed with the placid responses of "Wife," Beachcomber's examples of extreme state intrusion and social investigation aimed to amuse, but they also highlighted Conservative anxieties about government inspectors. Privacy as a value was

\footnotetext{
${ }^{104}$ Berridge, Marketing Health, 188.

105 Pixie Wilson and Virginia Barker, The Campaign against Venereal Diseases (London, 1944), 3.

106 Beachcomber, "Conversations in an Englishman's Home," Daily Express, 8 April 1949, 4.
} 
entrenched in Western Europe by the late eighteenth century and articulated in England through variants on "an Englishman's home is his castle" from the seventeenth century onward. ${ }^{107}$ The Conservative Party had used "an Englishman's home" on election material in 1929 informing the public that "socialism would mean inspectors all round." 108 Following Labour gains in the 1906 election, Conservative Party literature had increasingly focused on defeating the specter of socialism. ${ }^{109}$ Conservative propaganda in the 1920s warned women in particular to be vigilant for "Communist spies. . . disguised as nurses and health workers" who would attempt to infiltrate the home. ${ }^{110}$ For some Conservatives, the Attlee government's insistence on retaining wartime controls, regulations, and surveillance mechanisms in peacetime "seemed the thin end of the wedge of totalitarianism." MP Bernard Braine told the Conservative Party annual conference in 1947 that seventeen separate ministries had the power to authorize entry into private houses. He exclaimed, "Today it is an official coming in to search your larder; tomorrow it may well be an official coming in to inspect your books and private papers . . . tomorrow it may well be a fascist state." 111 Such Conservative rhetoric was echoed in complaints received by the GSS after the war. ${ }^{112}$ Although hostility toward government inspectors and surveyors had been growing since the interwar period, with citizens increasingly protesting the "violation of their right to be left alone," the Second World War sharpened understandings of freedom and liberty. ${ }^{113}$ One complainant wrote, "I cling rather obstinately to the idea . . . of freedom for which I fought during the recent war." 114 Another described the use of proxies as an "un-English procedure."115 The phrase "An Englishman's home is his castle" appeared in several complaints suggesting that state-run surveys and social investigation could be perceived as threats to a nationally specific notion of liberty intertwined with privacy. ${ }^{116}$

Rhetoric like "snoopers" and "an Englishman's home is his castle" also conflated invasions of privacy and property. ${ }^{117}$ They connected anxieties around the survey

\footnotetext{
${ }^{107}$ Amanda Vickery, "An Englishman's Home Is His Castle? Thresholds, Boundaries and Privacies in the Eighteenth-Century London House," Past and Present 199, no. 1 (2008): 147-73, at 149.

108 "Socialism Would Mean Inspectors All Round," 1929, POSTER 1929-1931, Conservative Party Archive, Poster Collection, Bodleian Library, Oxford.

${ }^{109}$ John D. Fair and John A. Hutcheson, Jr, "British Conservatism in the Twentieth Century: An Emerging Ideological Tradition," Albion: A Quarterly Journal Concerned with British Studies 19, no. 4 (1987): 549-78, at 551 and 559.

110 David Jarvis, "Mrs Maggs and Betty: The Conservative Appeal to Women Voters in the 1920s," Twentieth Century British History 5, no. 2 (1994): 129-52, at 148.

${ }^{111}$ Martin Francis, "Set the People Free'? Conservatives and the State, 1920-1960," in Francis and Zweiniger-Bargielowska, Conservatives and British Society, 58-77, at 61-62.

112 TNA, RG 40/133, Complaints Received from Members of the Public Interviewed by S. S. Investigators, 4 August 1948; TNA, RG40/134, Complaints Received from Members of the Public Interviewed by S. S. Investigators, Fieldworker Report, 19 July 1950.

113 Deborah Cohen, Family Secrets: Shame and Privacy in Modern Britain (Oxford, 2013), 196.

114 TNA, RG 40/133, Complaints Received from Members of the Public Interviewed by S. S. Investigators, 9 December 1947.

115 TNA, RG 40/133, Complaints Received from Members of the Public Interviewed by

S. S. Investigators, 4 August 1948.

116 Cohen, Family Secrets, 6, 196.

117 David Vincent, The Culture of Secrecy: Britain, 1832-1998 (Oxford, 1998), 143, 266.
} 
to fears of burglary-satirized by the Express's Beachcomber as "he broke in while I was out" - and suggested a limit to the level of state intrusion deemed acceptable. An association between two very different forms of home invasion was evident in complaints received, especially those motivated by the controversial income question. In 1945, Fife Clark warned Louis Moss that the public were concerned by "questions about income" and wanted "to check the bona fides" of investigators, conflating anxieties about income questions with doubts about the legitimacy of the survey. ${ }^{118}$ In response, fieldworkers were issued with official cards explaining the purpose of the GSS, reassuring participants that interviews were anonymous and voluntary and informing them that local police were aware the survey was working in their district. ${ }^{119}$ These assurances did not solve the problem, however. In January 1947, Fife Clark wrote to Moss again, expressing his displeasure at complaints of fieldworkers refusing to show their cards and asking Moss to tighten procedure. ${ }^{120} \mathrm{By}$ 1952, the issue required intervention in the House of Commons, with a Scottish member of Parliament calling for "strict instructions to all 'snoopers' that they must produce their credentials." $" 121$

But even when GSS fieldworkers informed the police of their presence and showed authorization cards, there were still anxieties. Eloise Moss argues that in the first half of the twentieth century, emotive advertisements for burglary insurance exacerbated an "existing culture of fear" about crime and burglary. ${ }^{122}$ By the 1930s, such advertisements were featured in a wide range of newspapers, encouraging the perception of burglary as a "universal threat" and a "pervasive aspect of everyday life."123 Through visual images of ransacked drawers, insurers stoked fears not just of the loss of material goods but of the violation of privacy through home invasion. ${ }^{124}$ Some members of the public viewed social surveys as similarly invasive. In July 1948, a chief constable in York notified the GSS that he had received complaints about the survey. 125 The medical officer of health for Southgate, a North London suburb, although generally supportive of the survey, wrote, "[w]ith the amount of house-breaking. . . going on . . . householders are naturally sceptical about callers who appear and ask questions."126 These anxieties reached their logical conclusion when a fieldworker, a Miss Ratter, was "suspected . . . of being an accomplice to a burglar" by a couple in Guildford and was interviewed by the police. In her report of the incident, Ratter was understanding of the mix-up. She wrote, "They had

\footnotetext{
118 TNA, RG 40/198, Health Index Correspondence, Thomas Fife Clark to Louis Moss, 9 October 1945.

119 TNA, RG 40/133, Complaints Received from Members of the Public Interviewed by S. S. Investigators, January 1947.

${ }^{120}$ TNA, RG 40/133, Complaints Received from Members of the Public Interviewed by S. S. Investigators, Thomas Fife Clark to Louis Moss, 15 January 1947.

121 "House of Commons," Times (London), 18 June 1952, 4.

122 Eloise Moss, "Burglary Insurance and the Culture of Fear in Britain, c. 1889-1939," Historical Journal 54, no. 4 (2011): 1039-64, at 1044.

${ }^{123}$ Moss, "Burglary Insurance," 1054-55, 1046.

${ }^{124}$ Moss, 1054.

125 TNA, RG 40/133, Complaints Received from Members of the Public Interviewed by S. S. Investigators, 30 June 1948.

126 TNA, RG 40/133, Complaints Received from Members of the Public Interviewed by S. S. Investigators, 10 July 1947.
} 
every excuse to suspect me," explaining that the house next door had been ransacked while a female accomplice distracted the occupants with "questions." 127 GSS fieldworkers recognized that their work could be misconstrued in this way and were understanding of a(n English) man's right to defend his home.

Although some female complainants did use the term in relation to the survey, Jon Lawrence suggests that men generally tended to be "more determined to maintain the strict domestic privacy of the "Englishman's castle" than women were. ${ }^{128}$ Likewise, Eloise Moss has shown how insurance advertisements presented the safety of domestic spaces as the responsibility of male heads of household. ${ }^{129}$ Protective masculinity was also provoked by interviewers' failure to inform people that participation in the survey was voluntary. The importance of gaining consent before an interview was explained to staff at the GSS, but reliability of results rather than ethical practice was emphasized. In his instructions to interviewers, Percy Stocks wrote, "[c]o-operation in answering the questions is entively voluntary. . . information given unwillingly about health is unlikely to be reliable."130 But Stocks also instructed interviewers to encourage the public to answer their questions: "The value of their answers should be stressed since there is no other practical way of obtaining such information."131 As a result, fieldworkers did not consistently tell survey subjects they could refuse, often only informing them that it was voluntary in an information leaflet provided at the end of the questionnaire. ${ }^{132}$ Ten of the available complaints were about this issue. Six of those were from men writing in on behalf of their wives, taking issue with the intrusion occurring in their absence. A similar feeling was expressed by an unlikely source: a Ministry of Health officer who, arriving home to find his wife in the middle of an interview, objected and called the process to a halt. The exasperated fieldworker wrote, "[a]s the Survey is being done for the Ministry of Health. . . some cooperation might be expected." But Fife Clark, who was handling the complaint, argued that ministry "officers . . . in their private lives are in exactly the same position as any other members of the British public. They are quite entitled to refuse."133 The official's status as a member of the "public" of public health brought the state into his home, but his membership of the "British public" also gave him the right of refusal.

Protective instincts surfaced for other female members of the household besides wives. In 1949 a man from Surrey wrote to his MP complaining that a "lady. . . spent some time making very personal enquiries of the governess." He claimed the survey was "a gross infringement of. . . liberty" and went on to express fears that the public would become immune to such violations-a view represented in extreme form by Beachcomber's placid "Wife." He feared the survey would "induce the unthinking public" to imagine themselves "at the beck and call of the

127 TNA, RG 40/133, Complaints Received from Members of the Public Interviewed by S. S. Investigators, 10 January 1948.

${ }^{128}$ Lawrence, "Class, 'Affluence," 285.

129 Moss, "Burglary Insurance," 1054.

${ }^{130}$ TNA, RG 26/26, Survey of Sickness: Instructions to Interviewers; Stocks's emphasis.

${ }^{131}$ TNA, RG 26/26, Survey of Sickness: Instructions to Interviewers; Stocks's emphasis.

132 TNA, RG40/134, Complaints Received from Members of the Public Interviewed by S. S. Investigators, 29 November 1949.

133 TNA, RG 40/15, Survey of Sickness Pilot Questionnaire, Thomas Fife Clark to Louis Moss, 15 August 1947. 
government." In his complaint, however, he presented himself as a hindrance to creeping state control: "I only wish that the lady had called to question me."134 While this man and the Ministry of Health officer were in some ways in "exactly the same position" as other members of the public, they and many of the male complainants were very different from the usual subjects of social surveys and marked themselves out as such. Public-health campaigns and social surveys were more often aimed at women and children. Even though millions of men had presented themselves to medical boards between 1939 and 1945 for medical exams to assess their suitability for military service, the experience of being surveyed at home and in peacetime was a harder pill to swallow. ${ }^{135}$

Although the "domestic privacy of the 'Englishman's castle" was not a uniquely middle-class phenomenon, surveyors in the 1930s had found more visible "reluctance" to answer questions on the part of "the middle class and better off working class"- a Conservative constituency-than the marginalized poor. ${ }^{136}$ It may be that marginalized communities, especially the unemployed, were more experienced in engaging with the state and had felt in the past the consequences of not cooperating. ${ }^{137}$ Means testing in the 1930s meant that poorer families would have been practiced in giving the "right" answers and treading the fine line between respectability and impoverishment necessary to be deserving of state assistance-a practice Lisa McKenzie terms "getting by." 138 By the interwar period, anxieties around state "snoopers," privacy, and liberty were shared by a broader, newspaper-reading public, but the ability to push back and be listened to was more of a middle-class phenomenon. ${ }^{139}$ In surveying a representative sample of the whole adult population, the Survey of Sickness brought a different section of the public - men, and middle-class ones at that-under the focus of the survey and government intervention. These men were unhappy about their bodies, wives, homes, businesses, and staff being subject to the scrutiny of the survey, but they also had the means and the words provided by wartime experience and Conservative political rhetoric to express their displeasure.

\section{"I HAD BEEN PARTICIPATING IN YET ANOTHER WASTE OF PUBLIC MONEY AND PRIVATE TIME"}

Another common concern inflected by Conservative rhetoric was that the survey was a waste of time and government resources. Criticisms of wasteful public expenditure increased after the First World War as state spending grew and the number of people

134 TNA, RG40/134, Complaints Received from Members of the Public Interviewed by S. S. Investigators, 8 December 1949.

${ }^{135}$ Berridge, Marketing Health, 188; Emma Newlands, Civilians into Soldiers: War, the Body and British Army Recruits, 1939-45 (Manchester, 2014), 26-27.

${ }^{136}$ Lawrence, "Social-Science Encounters," 215; Lawrence, "Class, Affluence,” 285; Llewellyn Smith, New Survey, 32-33.

${ }^{137}$ Stephanie Ward, "The Means Test and the Unemployed in South Wales and the North-East of England, 1931-1939," Labour History Review 73, no. 1 (2008): 113-32, at 117; Vincent, Culture of Secrecy, 23.

${ }^{138}$ Lisa McKenzie, Getting By: Estates, Class and Culture in Austerity Britain (Bristol, 2015), 48; David Vincent, Poor Citizens: The State and the Poor in Twentieth Century Britain (London, 1991), 13.

139 Cohen, Family Secrets, 8, 196-97. 
paying income tax multiplied. 140 "Sensational stories" of public waste featured heavily in the popular press from the 1920s and anti-waste campaigns were fiercely promoted in the Daily Mail and Daily Mirror. ${ }^{141}$ These concerns were echoed in the immediate aftermath of the Second World War when scarcity further sharpened attitudes to waste. ${ }^{142}$ In responses to the Survey of Sickness, there was a sense that both individual citizens and the state had better uses for their time and resources. Fourteen of the sixty-nine complaints mentioned waste and criticized the survey in the context of wartime shortages. These complaints were often linked to other concerns, such as the perception of the survey as an infringement of liberty, but were frequently gendered. A focus on waste proved a popular form for women to express their grievances. Their complaints can be read as expressions of political subjectivity alongside other home-centered claims to citizenship.

A preoccupation with government waste was, again, particularly apparent among middle-class survey respondents. Six of the fourteen complainants identified themselves as middle class, brought home large incomes, or showed clear material markers such as owning a telephone or television (at a time when only 4.3 percent of the population owned the latter). ${ }^{143}$ One man who earned $£ 20$ a week and was wealthy enough to have both a library and tennis court in his home decided after completing an interview, a process he had enjoyed, that he objected to the survey "in principle." He wrote, "Your canvasser. . . was very courteous and competent. . . [but] if . . . your organisation had given me an opportunity of considering this more fully, my answer would most certainly have been negative. As it happened my house was invaded without notice and I only realised when it was finished that I had been participating in yet another waste of public money and private time."144

A fifty-seven-year-old housewife from Croydon, South London, the wife of a skilled manual worker and a member of the aspirational working class, was much clearer from the outset that she thought the survey was a waste of her time. She wrote that having "felt irritated and puzzled at the call" and having informed the fieldworker that she was "very busy and pressed for time," she was "now glad to say that all [her answers] were not true." 45 This woman's irritation with state surveillance came just months before a surge in Conservative votes from women in the 1951 general election. ${ }^{146}$ Significantly the fieldworker in question, a Miss Trumper, wrote that she did not "recall having had any difficulty" with the woman. Liz Stanley and Margaretta Jolly note that in letters we see a "subtle interchange between fantasy, writing and relationship" rather than "outpourings of the true self." 147 While there might have been an element of fantasy in this woman's

\footnotetext{
140 Andrew McDonald, "The Geddes Committee and the Formulation of Public Expenditure Policy, 1921-1922," Historical Journal 32, no. 3 (1989): 643-74, at 644.

${ }^{141}$ McDonald, "Geddes Committee," 645-46.

142 James Hinton, "Militant Housewives: The British Housewives' League and the Attlee Government," History Workshop Journal 38, no. 1 (1994): 128-56, at 132; Roodhouse, Black Market Britain, 240.

${ }^{143}$ Langhamer, "Meanings of Home," 353.

${ }^{144}$ TNA, RG40/134, Complaints Received from Members of the Public Interviewed by S. S. Investigators, 21 July 1950.

145 TNA, RG40/134, Complaints Received from Members of the Public Interviewed by

S. S. Investigators, 8 May 1951.

${ }_{146}$ Zweiniger-Bargielowska, "Explaining the Gender Gap," 201.

${ }^{147}$ Margaretta Jolly and Liz Stanley, "Letters as / Not a Genre," Life Writing 2, no. 2 (2005): 91-118, at 93.
} 
claims about her actions in the moment, her letter served to rearticulate her relationship with the survey from compliant subject to active refuser. It raises the possibility as well that she vocalized a grievance shared by others whose protests also went unacknowledged by survey staff and who chose not to write in.

Indeed, her complaint was echoed by another woman; "What housewife has time to answer questions . . . in the middle of the day when she is dishing up the midday meal." "148 This complaint was provoked by a GSS survey on shortages that focused on the views of housewives. While the woman in question recognized that shortages were a concern, she let her exasperation show: "Apparently we are not short of civil servants to come round requesting interviews-at inconvenient times!" Whether because of or despite of the fact that women were frequently the focus of social surveys as austerity brought their work into the political domain, she was not the only housewife to express irritation at being questioned. ${ }^{149}$ In 1950, a representative of the Scottish Housewives Association wrote to the GSS on behalf of housewives who "resent this interference and have no time for it." 91 She stated, "[w]e are advising all our members that should they be approached they should refuse the information demanded, as we regard it as an infringement of the liberty of the subject. Britain is still supposed to be a free country." 150

Her use of the words "liberty" and "free country" spoke to concerns beyond time management. The Scottish Housewives Association was a counterpart to the British Housewives League, a largely middle-class, militant, consumer organization that campaigned against rationing in the 1940s and went on to mount a campaign against fluoridation in the 1950s, perceiving any "unnecessary controls" as a "totalitarian threat." 151 James Hinton suggests that "militant housewife' was a contradiction in terms, as housewives 'were people who coped."'152 Voluntary women's groups, such as the Mothers' Union, Women's Institute, and Townswomen's Guilds, representing hundreds of thousands of women who were full-time wives and mothers, emphasized a "gendered citizenship" based on housewives' "capacity to cope" and advise on domestic affairs. ${ }^{153}$ Yet as Amy Whipple has shown, the British Housewives League and sister organizations like the Scottish Housewives Association "challenged their members to become more educated, more active citizens"-advocating a more vocal, critical form of citizenship. ${ }^{154}$ In doing so, they critiqued the expansion of the state and argued that "even well-intentioned government interventions eroded liberty." The British Housewives League and the Scottish Housewives Association saw public health interventions like fluoridation as "robbing housewives of their time-honored responsibility for the education, nourishment and health of the nation by foisting the opinions of 'so called experts' on private

148 TNA, RG40/133, Complaints Received from Members of the Public Interviewed by S. S. Investigators, 23 February 1948.

${ }^{149}$ Hinton, "Militant Housewives," 137-38.

150 TNA, RG40/133, Complaints Received from Members of the Public Interviewed by S. S. Investigators, 3 June 1950.

${ }^{151}$ Amy C. Whipple, "'Into Every Home, into Every Body': Organicism and Anti-Statism in the British Anti-Fluoridation Movement, 1952-1960," Twentieth Century British History 21, no. 3 (2010): 330-49, at 332; Roodhouse, Black Market Britain, 240.

${ }^{152}$ Hinton, "Militant Housewives," 149-50.

${ }^{153}$ Hinton, 137-38; Beaumont, Housewives and Citizens, 62.

${ }^{154}$ Whipple, "Into Every Home, into Every Body," 334. 
homes and families"; the GSS was seen as a tool of this assumed expertise. ${ }^{155}$ In fact, it turned out that the Scottish Housewives Association had the wrong survey. Moss wrote back to explain that the GSS was not surveying in Scotland at that time and that the Scottish Housewives Association must have been confusing his organization with a market research agency.

Beaumont has shown how most middle-class women's groups responded enthusiastically to government requests for their views in order to place the voices of housewives "right at the heart" of postwar reconstruction. ${ }^{156}$ In surveying ordinary people and trusting women to act as proxies for members of their households, the GSS recognized the gendered expertise of the "citizen housewife." 157 Yet the above complaints suggests that some middle-class or aspirational working-class women, although more used to being the subjects of state inquiry than middle-class men, could still be pushed to a limit. These women utilized the same concepts of "liberty" and similar social connections to complain, but they wrapped their complaints in the narrative of "busy-ness." As individuals, they internalized the rhetoric of groups like the British Housewives League and Scottish Housewives Association and articulated an oppositional form of gendered citizenship, reaffirming the importance of their work in the home while simultaneously rejecting the state's place there.

Another complainant saw the value of the Survey of Sickness but could not comprehend why government resources were being "wasted" on her. She wrote at length:

I really cannot imagine why the Government should think it necessary to visit . . . a road like this which does not spell poverty. When one owns a house and pays rates amounting to over $£ 20$ a year and income tax, one hardly likes to be accosted at the door with questions about health ... It is an absolute intrusion and an indignity — as well as a waste of Government money... I pointed out to the visitor that the poorest person in the road . . . who is suffering from cancer in the face is the only one. . . needing help. . . It just seemed to me that the [fieldworker's] visit was entirely futile and unnecessary. ${ }^{158}$

At the root of this complaint was a misunderstanding of the purpose of the Survey of Sickness. The complainant failed to recognize that the survey aimed to understand the health of the whole population rather than to identify those in need of assistance, a point Louis Moss was quick to clarify. However, this complaint was also suggestive of middle-class shock and offense at being subject to the "intrusion and . . . indignity" usually reserved for the "poorest." 159 As David Vincent has articulated, there was a balance to be struck between rights lost and benefits gained on the "contested boundary between privacy and surveillance." ${ }^{\prime 60}$ In this case, the complainant had failed to appreciate the benefits of the survey to wider society, preferring to focus on the individual. By naming her neighbor and discussing her circumstances so frankly, she also

\footnotetext{
155 Whipple, 344.

156 Beaumont, Housewives and Citizens, 146

${ }^{157}$ Ina Zweiniger-Bargielowska, "Housewifery," in Women in Twentieth-Century Britain, ed. Ina Zweiniger-Bargielowska (Harlow, 2001), 149-64, at 156.

158 TNA, RG 40/16, Health Index Survey: General Correspondence, 29 July 1948.

159 Vincent, Culture of Secrecy, 23, 144.

${ }^{160}$ Vincent, Privacy, 101.
} 
showed an ironic lack of awareness of what might be considered an "indignity" or a loss of rights. ${ }^{161}$

Other less vocal members of the public may have also resented the imposition of the state surveys on their lives and on their time. The final question of a 1944 GSS inquiry into venereal disease asked, "What else do you think should be done to stamp out VD apart from publicity?" Only 56 percent of respondents made suggestions, with 39 percent recording a "don't know/no ideas" response and 5 percent making "no answer" at all. GSS researchers found that "analyses by education, income, sex, marital status and age" showed that in this survey, "certain groups of people have more constructive suggestions to make than others." 162 Sixty-seven percent of men made suggestions, compared with 48 percent of women, and 73 percent on a "higher income" did, compared with 54 percent on a "lower income."163 This inquiry was carried out in factories and asked workers to "sacrifice" their time even when they were "working on piece-rates." 64 Rather than being ignorant or apathetic, some people, male or female, might have answered "don't know" to get back to work more quickly, conscious of lost wages, or embarrassed, or unwilling to reveal the extent of their knowledge of sensitive subjects. ${ }^{165}$ In this light, claims of ignorance might have been a less confrontational form of resistance more accessible and familiar to some than outright refusal or complaint.

The GSS required everyone to be an expert in their own health while continuing to position women as experts in their families' health. For some women's organizations, this view enabled a greater claim to citizenship through involvement in postwar reconstruction, but others saw state intrusion as undermining their expertise within the home, or merely as an added burden on already busy lives made more difficult by government controls. Letters of complaint allowed individual middle-class women to form another narrative around expertise: that they were experts but had no obligation to share that expertise. These letters articulated an oppositional relationship with the state, a form of political subjectivity outside the boundaries of the survey that was unavailable to many women, especially working women, who may have resisted in other ways.

\section{"I DID NOT THINK SHE WAS GENUINE": THE RELATIVE AUTHORITY OF FIELDWORKERS}

Both men and women complained about the conduct of female fieldworkers and questioned their authority. Their grievances were not only with state surveillance and the breaches of privacy and disruption of schedules it brought but also with the women who enacted it. The authority of the state was conditional on members of the public recognizing it in the women working for the GSS. Whether members of the public did or not was informed by their relative positions in society and reflected existing power structures. Although some of those

\footnotetext{
161 TNA, RG 40/16, Health Index Survey: General Correspondence, 29 July 1948.

${ }^{162}$ Wilson and Barker, Campaign against Venereal Diseases, 53.

${ }^{163}$ Wilson and Barker, 54.

164 Box and Thomas, "Wartime Social Survey," 151-52.

${ }^{165}$ Kate Fisher, Birth Control, Sex, and Marriage in Britain 1918-1960 (Oxford, 2006), 6, 67.
} 
questioning the legitimacy of individual fieldworkers were motivated by political concerns or anxieties about burglaries or felt personally slighted, there were occasions when criticisms were informed by prejudices against the gender or ethnicity of the field staff.

In 1952, Douglas Marshall, MP for Bodmin in the southwest of England, passed a letter from his constituent, a doctor, on to the minister for health. The doctor, complaining about the Survey of Sickness, had written, "It is obvious that under the cloak of 'research' which is plain eyewash ... . we are being subjected to espionage by Government snoopers . . . in the form of interfering women ... paid a salary-out of taxation that we have to pay-to poke their noses into other peoples' affairs. This is when a large proportion of my patients are suffering in health from overwork due to lack of domestic help."166

The doctor's language- "espionage by Government snoopers" and "taxation"shows that he shared the concerns of other complainants about privacy, liberty, and the misuse of resources, yet his complaint was also very gendered. The words "interfering women" and his implicit suggestion that fieldworkers would be better employed as "domestic help" reveal anxieties about class, gender, and women's labor. This concern is striking as women had been employed in a similar capacity as health visitors for many decades; by the late 1940s, as many as six thousand women were visiting mothers across Britain. ${ }^{167}$ So-called "female characteristics" such as "tact and sympathy" were "prime requirements" for the face-to-face work of both health visitors and interviewers and could at times lead to their being mistaken for one another. ${ }^{168 \mathrm{~A}}$ Indeed, during the GSS's 1942 inquiry into diphtheria immunization, it was noted that "in a few cases the investigator was taken for a health visitor with consequent over estimation of the amount of sleep" by working-class mothers. ${ }^{168 \mathrm{~B}}$ In this context, it might seem odd that a medical professional would not recognize the similarities. Yet previously female health visitors had largely entered the homes of the poor, perhaps an underrepresented group among this doctor's patients who were lamenting the loss of domestic help. ${ }^{169}$ His skepticism of "research" indicates that his larger grievance was a professional and political one: an objection to the discipline of medical statistics and government interference in medicine epitomized by social medicine and the new National Health Service. ${ }^{170}$

Other complaints cast doubt on the legitimacy of fieldworkers by questioning their ethnicity or nationality. A man from Bradford, interviewed at the business he owned, wrote to register his "distaste" with the process and to ask if the fieldworker was "of British Stock." 171 Moss, aware that the woman concerned was "not a British subject," that she had "no nationality and [had] applied for naturalization,"

166 TNA, MH 55/991, Public Health Propaganda, Letter from Douglass Marshall to Harry Crookshanks, 16 March 1952.

167 Vincent, Privacy, 101.

168A Davies, "Health Visitor as Mother's Friend," 41, 47; Ellen Warne et al., "Women in Conversation: A Wartime Social Survey in Melbourne, Australia 1941-43," Women's History Review 12, no. 4 (2003): $527-45$, at 530 .

${ }_{1688}$ TNA, RG 23/23, Diphtheria Immunisation Enquiry, July-August 1942, 10.

169 Seth Koven, Slumming: Sexual and Social Politics in Victorian London (Princeton, 2004), 225.

170 Porter, Trust in Numbers, 205; Oakley and Barker, Private Complaints, 5-6.

${ }^{171}$ TNA, RG 40/133, Complaints Received from Members of the Public Interviewed by S. S. Investigators, 23 February 1948. 
attempted to gloss over the issue: "I take it you had no objection to the personal conduct of the investigator. . . we have every confidence in their integrity and scientific impartiality." 172 However, the complainant replied that it was a "simple question" and he wanted an answer. At this point, Bradford's regional organizer, Enid Swindlehurst, stepped in, writing to Moss, "Please . . . let me know of any action that may have to be taken. I sincerely hope however-bias, prejudice, aggressiveness or like qualities will not be upheld to the detriment of anyone whose fault may be seen in colour, race, creed only."173

That Swindlehurst felt the need to take this stand on behalf of her junior colleague is instructive. A year earlier, Moss had dismissed one of the few male fieldworkers for the crime of being "Canadian with perhaps a rather expansive manner" deemed "likely to upset" the "more reticent." British subject, he was deemed foreign in character by the surveyed of Chelsea, London, and, subsequently, his "Canadian" mannerisms were considered unprofessional by Moss. Criticisms based on ethnicity and nationality reflected a general racism in society at a time when Britishness and whiteness were becoming "increasingly synonymous," but in the pairing of these two incidents, we can further explore where the lines of "foreignness" were drawn in society and the survey. ${ }^{175}$

Moss's response to the Bradford businessman reflected contemporary discussions about social research methods that proposed that "evident racial characteristics [in fieldworkers] are undesirable in certain surveys but irrelevant in others." 176 Difference only mattered if it was seen to affect the survey adversely. Moss wrote that the GSS did "not normally employ" non-British fieldworkers, but he justified hiring this particular woman because she was highly skilled: "The girl [was] a qualified social worker with strong recommendations from academic people. . . we knew this one was good." 177 Moss's insistence on her "scientific qualifications and experience as a fieldworker" as well as her "reliability and efficiency" attempted to confer authority back onto the woman in question, while reaffirming the scientific credibility of the GSS. For Moss and his colleagues at the GSS, employing "competent investigators" was deemed more "important" than employing people who read as "British" in body and mannerisms. But the "foreignness" of fieldworkers, whether white or not, was a cause of concern to some letter writers, whose complaints served to conflate both physical and cultural differences with unprofessionalism, adding to their discomfort with the survey. The complaints show that the "material practical encounters" of surveys were fraught with prejudices and assumptions around gender and ethnicity that could undermine the authority of the fieldworkers and the GSS. ${ }^{178}$

172 TNA, RG 40/133, Complaints Received from Members of the Public Interviewed by S. S. Investigators, February 1948.

${ }^{173}$ TNA, RG 40/133, Complaints Received from Members of the Public Interviewed by S. S. Investigators, February 1948.

174 TNA, RG 40/133, Complaints Received from Members of the Public Interviewed by S. S. Investigators, 15 January 1947.

${ }^{175}$ Chris Waters, "Dark Strangers' in Our Midst: Discourse of Race and Nation in Britain, 19471963," Journal of British Studies 36, no. 2 (1997): 207-38, at 212.

${ }_{176}$ Claus Moser, Survey Methods in Social Investigation (London, 1958), 192.

177 TNA, RG 40/133, Complaints Received from Members of the Public Interviewed by

S. S. Investigators, February 1948.

178 Savage, Identities and Social Change, 12. 


\section{CONCLUSION}

Unknown to them, in March 1952 the fieldworkers of the Survey of Sickness conducted their final interviews and completed their schedules for the last time. The GSS had been under pressure to justify its expenditure since the election of the Conservative government in 1951, but in the spring of 1952, the Treasury set its sights specifically on the Survey of Sickness. In February, researchers working on the survey had met with treasury representatives. Despite making a "reasonable case . . . for continuing the Survey" and agreeing to cost-cutting procedures, they were not out of the woods. ${ }^{179}$ On 5 March, the treasury wrote to the minister for health, Harry Crookshank, remarking that the survey was "expensive as these things go" at $£ 25,000$ for the year and asking whether he felt it was "really necessary to continue this Survey in our present financial position." 180 While Crookshank was deliberating, he received MP Douglas Marshall's letter forwarding the complaint from his constituent, the doctor from Bodmin. As well as complaining about "espionage by Government snoopers" and "interfering women," Marshall's constituent included a further indictment against the survey: "Although this is the sort of thing at which one could hardly be surprised under Socialism, it does occasion surprise under an allegedly Conservative Government."181 Writing from one Conservative MP to another, Marshall argued that the survey "really [was], I think you will agree, going too far." ${ }^{\text {" }}$ " Crookshank replied, promising that "in light of this letter and also for other wider reasons" he "was anxious to look into the matter." 183 Two weeks later, Crookshank wrote to the treasury agreeing to "the immediate suspension" of the survey"

In subsequent parliamentary debates, the decision to suspend the survey was defended solely on economic grounds, but in the mind of Louis Moss, the GSS's director, it was this final letter of complaint that "settled the matter." 185 Although very few of the 300,000 people interviewed by the Survey of Sickness complained, those who did had their complaints heard. This article has used a selection of complaints made by members of the public about the Survey of Sickness to explore people's perceptions of the survey and their experiences of public health research in Britain in the immediate postwar period. Paired with newspaper reports, the complaints of a few can be suggestive of more widely held grievances, but it is also important to explore who complained and what they complained about. In sampling the whole adult population of England and Wales, the Survey of Sickness engaged a much broader public in public health research, a percentage of whom had not previously experienced the scrutiny of the state and had perhaps not previously recognized themselves as being a "public" of public health. Certain sections of the public were more able than others to respond to the survey, and the reasons and ways in which they did deepen our understandings of the hierarchies of expertise and the

179 TNA, MH 55/991, Public Health Propaganda, Memorandum, 19 February 1952.

180 TNA, MH 55/991, Public Health Propaganda, Letter, 5 March 1952.

181 TNA, MH 55/991, Public Health Propaganda, Letter, 16 March 1952.

182 TNA, MH 55/991, Public Health Propaganda, Letter, 18 March 1952.

183 TNA, MH 55/991, Public Health Propaganda, Letter, 22 March 1952.

184 TNA, MH 55/991, Public Health Propaganda, Letter, 1 April 1952.

${ }^{185}$ Moss, Government Social Survey, 159; Iain Macleod, Answer in the House of Commons, 2 July 1952, Parliamentary Debates, Commons, 5th series, vol. 503 (1951-52), col. 563. 
relationships between different publics and public health, while illuminating how gender and class informed understandings of citizenship in postwar Britain.

For Tom Crook, modern public health has involved multiple agents: experts and administrators matched with an active and accountable public, all of whom were both "objects and subjects of power." 86 Some sections of the public were able to wield more power than others, but what the complaints show us is that the role of the public in public health was not only varied but also up for negotiation. The middle classes, newly aware of their role as the subjects of public health research and rattled by what they perceived as increasing government intrusion into their lives when they felt they had "sacrificed most" under wartime rationing, were able and willing to construct complaints, and in doing so they affected change in the survey process. As John Clarke argues, when institutional practices are transgressive of public-private boundaries, institutions expend a lot of effort to mitigate the transgression by "establishing the notion of consent-and the maintenance of legitimacy in the face of dissent." 187 This effort was evident in the response of the GSS to certain criticisms. It gave its staff authority cards and developed an income card to allow people to reveal their income silently. The GSS met what Clarke terms the "modest demands of respect, dignity and recognition" articulated by its new, vocal public. These demands were "highly individual and personal," yet when shared, they evoked "norms of social and organisational conduct" and questioned the practices of the survey. ${ }^{188}$ Their complaints around privacy, liberty, waste, and the conduct of fieldworkers were sometimes couched in the anti-socialist rhetoric used by the Conservative Party and often reflected in the wider public discourse, especially in the popular press. From the latter we can infer that other sections of the public, such as working-class women, who were not clearly represented in the complaints, may have shared these grievances. These women may have resisted the survey in their own ways, through using "don't know" as a quick answer or deliberately misleading survey staff, but the survey's perception of them as ignorant of matters outside the home often obscured such forms of resistance.

Clarke notes that although complaints "may appear singular, personal and particular. . . they evoke a world of relationships (real and imagined)." 189 The complaints made against the Survey of Sickness reveal a complex set of relationships between different sections of the public and the British state: ones of power and prejudice, imagined and real. Complaints about privacy and liberty suggested that for some people there was a definite limit to what information the state should ask from citizens and how it should collect that information. These types of complaints were frequently made by men whose wartime experiences had sharpened their understanding of freedom and fed their notions of home as a private space to be protected at all costs. Complaints about wasted resources indicated that members of the public felt they had a stake in how public money was spent and that the survey was not a good use of it. People also valued their own time and contested the state's claims to it. These complaints, more commonly articulated by women frustrated with wartime controls, allowed them to present alternative narratives around citizenship

\footnotetext{
${ }^{186}$ Crook, Governing Systems, 17.

${ }^{187}$ Clarke, "Going Public," 263.

188 Clarke, 268.

189 Clarke, 268.
} 
and expertise - that they were experts in the home but had no obligation to share that expertise with the state. Finally, complaints about fieldworkers suggested that the authority of the state was contingent on people recognizing it and that this recognition was influenced by existing prejudices and power structures.

That the complaining public was largely middle class was significant not only because of their absorption of Conservative political rhetoric but because they had the economic and social capital to speak back to the survey and shape its practices, vocally negotiating their role as participants of research. At the same time, gendered and class-based perceptions of working-class women informed how their actions were perceived as passively noncompliant rather than deliberately transgressive. Unable to negotiate their role, this public could only subvert the survey by using other methods. In this way, the micro-politics of complaint reflected the politics of society in 1940s and early 1950s Britain-a politics in flux. The authority and legitimacy of the Social Survey was contingent on the recognition of that authority by the public. By expanding its public, the survey met with vocal respondents who threatened to disrupt hierarchies of state expertise. At the same time, it continued to engage an older, less vocal public in ways that reinforced those hierarchies. As public health evolved in the postwar period influenced by the ideology of social medicine, everyone became a participant in public health. But just as the role of public health was up for negotiation, so, too, was the role of the public, at least for those with the leverage to negotiate. 